REPORTS OF MORPHOLOGY
Official Journal of the Scientific Society of Anatomists,
Histologists, Embryologists and Topographic Anatomists
of Ukraine
journal homepage: https://morphology-journal.com

\title{
Biochemical parameters of blood and urine of rats at six-week administration of Nalbuphine
}

Vilkhova I.V.

Danylo Halytskyi Lviv National Medical University, Department of Normal Anatomy, Lviv, Ukraine

\author{
ARTICLE INFO \\ Received: 30 November 2020 \\ Accepted: 12 January 2021 \\ UDC: $616.15+616.63)-071: 615.212 .7]-$ \\ 092.9
}

\section{CORRESPONDING AUTHOR}

e-mail: irinamedik75@gmail.com Vilkhova I.V.

\begin{abstract}
Given the widespread use in medicine of opioid analgesics, today it is extremely important to study the morphofunctional changes of various organs with prolonged exposure to opioids. In the modern scientific literature there are works in which changes of biochemical indicators of blood at use of narcotic analgesics in experiment are covered. To study the changes in the biochemical parameters of blood and urine with long-term use of Nalbuphine is an important area of research. The aim of the study was to detect changes in some biochemical parameters of blood and urine of rats at sixweek administration of therapeutic doses of Nalbuphine. The study was based on 40 white adult male rats weighing 180-260 g, which were injected daily for six weeks with Nalbuphine injection $20 \mathrm{mg}$ daily, intramuscularly in therapeutic doses. Daily diuresis and creatinine content were determined in urine samples. The content of total protein, creatinine, urea, calcium and phosphorus was determined in blood samples. The glomerular filtration rate was also determined by the clearance of endogenous creatinine. All statistical calculations were performed using $R$ Studio v.1.1.442 and $R$ Commander v.2.4-4 software. The results of the study showed that six weeks of therapeutic doses of Nalbuphine affects the filtration and reabsorption function of the kidney. The use of Nalbuphine for two weeks does not cause significant changes in biochemical parameters, but the established deviations may indicate the first signs of renal dysfunction. Further use of Nalbuphine, including the end of the sixth week of the experiment, leads to significant changes in the filtration and reabsorption functions of the kidneys, as evidenced by statistically significant changes in the biochemical parameters of blood and urine of rats. The data of the study can be used to compare with changes in the functional state of the kidneys caused by prolonged use of Nalbuphine, its withdrawal and the use of other drugs in combination with Nalbuphine. It is also advisable to compare the results of the study with the morphological changes of the kidneys at different times of use of Nalbuphine.

Keywords: kidney, opioids, biochemical parameters.
\end{abstract}

\section{Introduction}

It is known that opioids are effective drugs in the symptomatic treatment of chronic pain of various etiologies, but have a toxic effect with prolonged use $[4,17,19]$. Current issues for now are the study of morphofunctional changes in various organs under the influence of opioids [9, 14, 20]. Currently, there are works that highlight the changes in the biochemical parameters of the blood when using narcotic analgesics in the experiment $[10,13]$. The morphofunctional state of the kidney under the influence of various drugs and chemical compounds is studied by many scientists [3, 24]. A number of studies are devoted to the study of changes in the structure and biochemical parameters of renal function with the use of opioids. Morphological changes of the kidney with the use of opioids were studied both on autopsy material and in an experiment [7, 11, 27]. Intravenous use of heroin leads to nephropathy, which is characterized by a morphological picture of focal and segmental glomerulosclerosis. This nephropathy was defined as heroin-associated in the early 1970s [21] and was found to be caused by the toxic effects of substances used to chemically process "street" heroin [6, 23]. Cases of renal lipoidosis detected by renal biopsy of patients using Methadon have been described [21]. Chronic kidney damage with opioid use may occur due to the method of 
drug administration, in particular intradermal drug administration to cause amyloidosis $[15,16]$. Thirty-day administration of morphine and tramadol in the experiment on rats revealed vacuolation of epithelial cells of the nephron tubules, interstitial mononuclear infiltration, focal necrosis and hemorrhage [1]. Among the causes of acute kidney damage when using opioids may be renal ischemia, resulting in decreased glomerular filtration rate, hypotension, dehydration, as well as rhabdomyolysis and acute urinary retention $[5,15]$. Opiate use may be a risk factor for decreased renal function and/or albuminuria [18]. A study of the relationship between the use of analgesics, including opioids, with biomarkers of chronic kidney disease in a representative sample of adults in the United States found higher rates of albuminuria when using prescription opioids compared with non-opioids [2]. Prolonged administration of Tramadol and Morphine in the experiment leads to increased creatinine levels [1].

In view of the above, the study of biochemical parameters of blood and urine with long-term administration of opioid analgesics, in particular Nalbuphine, is an important area of research.

The aim of our study was to identify changes in some biochemical parameters of blood and urine of rats with a six-week administration of Nalbuphine therapeutic doses.

\section{Materials and methods}

The studies were performed on 40 white sexually mature male rats weighing $180-260 \mathrm{~g}$. The animals were kept in a vivarium on a standard diet with free access to water, constant humidity and temperature [8].

The work was carried out in accordance with the "Rules for the use of experimental animals", which corresponds to the provisions of the Declaration of Helsinki. Experimental animals were administered Nalbuphine injection $20 \mathrm{mg}$ daily for six weeks, intravenously in therapeutic doses. The control group received intramuscular injections of saline for six weeks.

Marked and weighed animals were kept in metabolic cells the day before blood collection and daily diuresis and urine creatinine were determined. Blood for the study was collected after intraperitoneal administration of sodium thiopental from the inferior vena cava and the content of total protein, creatinine, urea, calcium and phosphorus was determined. In order to assess the functional status of the kidneys, the glomerular filtration rate was determined by the clearance of endogenous creatinine [12].

The data obtained by us were checked for the normality of the distribution using the indicators of the asymmetry and excess coefficients, as well as using the Shapiro-Wilk test. All statistical calculations were performed using $\mathrm{R}$ Studio v. 1.1.442 and R Commander v.2.4-4.

\section{Results}

Changes in some biochemical parameters of rat blood and urine have been reported with daily intramuscular administration of Nalbuphine therapeutic doses. The data are presented in Table 1.

In the study, at 6 weeks of therapeutic doses of Nalbuphine, serum protein values tended to decrease in the second and fourth weeks of the experiment compared with the control group $(65.90 \pm 4.58) \mathrm{g} / \mathrm{L}$ and amounted to $(62.40 \pm 3.81) \mathrm{g} / \mathrm{L}$ and $(62.40 \pm 2.50) \mathrm{g} / \mathrm{L}$, respectively. However, these changes had no statistical confirmation.

Serum urea values after two and four weeks had no statistically significant difference compared with the control group ( $p>0.05$ ). After 6 weeks of the experiment, the average value of urea was statistically significantly higher $(p<0.05)$ compared with the control group and was $(7.623 \pm 0.729)$ $\mathrm{mmol} / \mathrm{L}$ with the control group indicator $(5.914 \pm 0.719)$ $\mathrm{mmol} / \mathrm{L}$.

After two weeks of the experiment, a tendency to increase the level of creatinine in the serum $(53.02 \pm 7.56) \mu \mathrm{mol} / \mathrm{L}$ was found, although compared with the control value of the average value $(48.35 \pm 10.83) \mu \mathrm{mol} / \mathrm{L}$, this was not confirmed statistically $(p<0.05)$. In the fourth and sixth weeks of the experiment there was a significant $(p<0.05)$ increase in the value of creatinine compared with the control and the

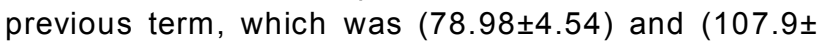
7.4) $\mu \mathrm{mol} / \mathrm{L}$, respectively.

Table 1. Indicators of protein, urea creatinine, blood calcium and phosphorus, daily diuresis, urine creatinine and glomerular filtration rate of rats at 6 weeks of therapeutic doses of Nalbuphine, $M \pm S D(n=10)$.

\begin{tabular}{|l|c|c|c|c|}
\hline \multicolumn{1}{|c|}{ Indexes } & Control & 2 weeks & 4 weeks & 6 weeks \\
\hline Total protein, g/L & $65,90 \pm 4,58$ & $62,40 \pm 3,81$ & $62,40 \pm 2,50$ & $64,40 \pm 3,57$ \\
\hline Urea, mmol/L & $5,914 \pm 0,719$ & $6,222 \pm 0,468$ & $5,732 \pm 0,354$ & $7,623 \pm 0,729^{* \circ}$ \\
\hline Blood creatinine, $\mu \mathrm{mol} / \mathrm{L}$ & $48,35 \pm 10,83$ & $53,02 \pm 7,56$ & $78,98 \pm 4,54^{* \circ}$ & $107,9 \pm 7,4^{* \circ}$ \\
\hline Calcium, mmol/L & $2,341 \pm 0,163$ & $2,157 \pm 0,086^{*}$ & $2,394 \pm 0,097^{\circ}$ & $2,391 \pm 0,090^{* *}$ \\
\hline Phosphorus, $\mathrm{mmol} / \mathrm{L}$ & $2,256 \pm 0,178$ & $2,424 \pm 0,049^{*}$ & $2,317 \pm 0,113$ & $2,115 \pm 0,118^{\circ}$ \\
\hline Daily diuresis, $\mathrm{ml} / \mathrm{day}$ & $8,680 \pm 2,613$ & $9,520 \pm 1,630$ & $11,10 \pm 1,96^{*}$ & $15,85 \pm 1,79^{* \circ}$ \\
\hline Urine creatinine, $\mu \mathrm{mol} / \mathrm{L}$ & $2535 \pm 458$ & $2829 \pm 237$ & $1521 \pm 138^{* \circ}$ & $3237 \pm 130^{* \circ}$ \\
\hline Glomerular filtration rate, $\mu / \mathrm{min}$ & $307,0 \pm 96,1$ & $367,4 \pm 74,0$ & $146,6 \pm 31,2^{* 0}$ & $330,4 \pm 36,7^{\circ}$ \\
\hline
\end{tabular}

Notes: ${ }^{*}-p<0,05$ compared to control; ${ }^{\circ}-p<0,05$ compared to the previous term of the experiment; ${ }^{* \star}-p<0,05$ compared with the second week of the experiment. 
In the second week of the experiment, the parameters of

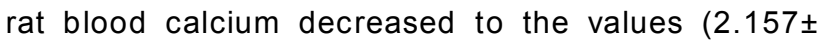
$0.086) \mathrm{mmol} / \mathrm{L}$, which was statistically significant $(p<0.05)$ compared with the control group $(2.341 \pm 0.163) \mathrm{mmol} / \mathrm{L}$. However, later, after 4 and 6 weeks of the experiment, the calcium values increased and were statistically significantly higher $(p<0.05)$, compared with the calcium values in the second week of the experiment and were (2.394 \pm $0.097) \mathrm{mmol} / \mathrm{L}$ and $(2.391 \pm 0.090) \mathrm{mmol} / \mathrm{L}$, respectively. Such values did not have a statistically significant difference with the control group.

Rat blood phosphorus values in the second week significantly $(p<0.05)$ increased to $(2.424 \pm 0.049) \mathrm{mmol} / \mathrm{L}$ compared with the control group $(2.256 \pm 0.178) \mathrm{mmol} / \mathrm{L}$. In the fourth week of the experiment, blood phosphorus values decreased slightly compared to the previous term and amounted to $(2.317 \pm 0.113) \mathrm{mmol} / \mathrm{L}$. At the sixth week of the experiment, the serum phosphorus concentration continued to decrease and reached the minimum values $(2.115 \pm 0.118) \mathrm{mmol} / \mathrm{L}$, which is significantly lower $(p<0.05)$ than the previous term. It should be noted that compared with the control group, the decrease in phosphorus concentration was insignificant $(p>0.05)$.

The tendency to increase the daily diuresis was observed in the second week of the experiment $(9.520 \pm 1.630) \mathrm{ml} / \mathrm{day}$, although the difference was not statistically significant compared with the control group, where the daily diuresis was $(8.680 \pm 2.613) \mathrm{ml} /$ day. A significant increase in daily diuresis compared to the control indicator was found after 4 weeks of the experiment - (11.10 \pm 1.96$) \mathrm{ml} /$ day. After six weeks of the experiment, the daily diuresis was $(15.85 \pm 1.79) \mathrm{ml} /$ day and was statistically significantly higher than the control group and the previous term.

After two weeks of the experiment, there was a tendency to increase the urinary creatinine $(2829 \pm 237) \mu \mathrm{mol} / \mathrm{L}$, although the difference was not statistically significant compared with the control group $(2535 \pm 458) \mu \mathrm{mol} / \mathrm{L}$. After four weeks of the experiment, a significant sharp (1.67 times), compared with the control group, a decrease in urine creatinine $(1521 \pm 138) \mu \mathrm{mol} / \mathrm{L}(p<0.05)$. After six weeks of the experiment, the level of urine creatinine increased 2.13 times compared with the fourth week of the experiment and 1.28 times compared with the control group and was $(3237 \pm 130) \mu \mathrm{mol} / \mathrm{L}$, which was statistically significant as when comparing this value in period of 4 weeks, and with similar numerical values obtained in the control group.

After two weeks of the experiment, there was a tendency to increase the glomerular filtration rate $(2829 \pm 237) \mu \mathrm{l} / \mathrm{min}$, although the difference was not statistically significant compared with the control group $(307.0 \pm 96.1) \mu \mathrm{l} / \mathrm{min}$. In the fourth week of the experiment, the glomerular filtration rate decreased sharply $(146.6 \pm 31.2) \mu \mathrm{l} / \mathrm{min}, 2.1$ times compared with the control group. At the end of the sixth week of the experiment, the glomerular filtration rate increased 2.25 times compared to the previous term, is slightly higher than the control group and is $(330.4 \pm 36.7) \mu \mathrm{mol} / \mathrm{L}$.

\section{Discussion}

Prolonged use of opioid analgesics leads to changes in the structure and function of various systems and organs, including the kidneys $[25,26]$. Given the use in medical practice, in particular in chronic pain syndrome, therapeutic doses of Nalbuphine, there is a need to study the morphofunctional changes of the kidneys with long-term use of this drug in the experiment.

As a result of our biochemical study of some indicators of blood and urine of rats under the conditions of six weeks of exposure to Nalbuphine, the following changes in the functional state of the kidney were found. The use of therapeutic doses of Nalbuphine for two weeks leads to minor changes in serum protein, urea, creatinine, calcium and phosphorus, daily diuresis and urinary creatinine, glomerular filtration rate. Such changes in indicators are not statistically significant compared with the control group, but may indicate the initial signs of changes in renal structures and the beginning of the development of filtration and reabsorption disorders, which at this time are still compensated.

Researchers data suggest that long-term use of opioids may lead to a decrease in glomerular filtration rate [18]. At the end of the fourth week of the experiment, we observed a significant decrease in glomerular filtration rate due to a 1.63-fold increase in serum creatinine combined with a sharp 1.67-fold decrease in urinary creatinine. At this time, impaired renal filtration function appears due to a sharp decrease in glomerular filtration rate. The revealed significant increase in the daily diuresis also indicates a violation of the reabsorption function of the kidneys.

The mechanisms of opioid-related renal failure are renal ischemia (prerenal factor), acute tubular necrosis, and impaired urinary outflow due to impaired bladder innervation (postrenal factor) [15]. At the end of the sixth week of the experiment, we observed progression of renal filtration function impairment, as evidenced by a 2.23 -fold increase in serum creatinine and a 1.29-fold increase in serum urea relative to the control group. Such changes in the indicators of nitrogen excretory function of the kidney may indicate damage to the structure of the renal corpuscle. However, an increase in the glomerular filtration rate may indicate the accession of compensatory mechanisms in this period. The use of Nalbuphine for six weeks revealed a deepening of renal reabsorption function, as evidenced by an increase in the number of daily diuresis and a tendency to decrease serum phosphorus, and indicates damage to the convoluted tubules of the nephron.

The data of the study can be used in the future to compare with changes in the functional state of the kidneys caused by prolonged use of Nalbuphine, its withdrawal and the use of other drugs in combination with Nalbuphine. Also, the results of the study should be compared with the 
morphological changes of the kidneys at different periods of Nalbuphine use.

\section{Conclusions}

1. The results of the study of therapeutic doses Nalbuphine during six weeks indicate an effect on the filtration and reabsorption function of the kidney by this drug.

2. The use of Nalbuphine for two weeks does not cause

\section{References}

[1] Atici, S., Cinel, I., Cinel, L., Doruk, N., Eskandari, G., \& Oral, U. (2005). Liver and Kidney Toxicity in Chronic Use of Opioids: An Experimental Long Term. Treatment Model. J. Biosci., 30(2), 245-252. doi: 10.1007/BF02703705

[2] Barbosa-Leiker, C., McPherson, S., Daratha, K., Alicic, R., Short, R., Dieter, B. ... Tuttle, K.R. (2016). Association between prescription opioid use and biomarkers of kidney disease in US adults. Kidney Blood Press Res., 41(4), 365-373. doi: 10.1159/000443436

[3] Chala, K.M., Khodorovska, A.A., Chernikova, H.M., \& Popova, I.S. (2018). Зміни екскреторної функції нирок у білих щурів під впливом тривалого виживання малих доз хлористих сполук кадмію та талію [Changes in excretory renal function in white rats under the influence of long-term survival of small doses of cadmium and thallium chloride compounds]. Буковинський медичний вісник - Bukovynian Medical Bulletin, 22(3(87)), 100-104.

[4] Chou, R., Ballantyne, J.C., Fanciullo, G.J., Fine, P.G., \& Miaskowski, C. (2009). Research gaps on use of opioids for chronic noncancer pain: findings from a review of the evidence for an American Pain Society and American Academy of Pain Medicine clinical practice guideline. J. Pain., 10(2), 147-59. doi: 10.1016/j.jpain.2008.10.007

[5] Feng, G., Luo, Q., Guo, E., Yao, Y., Yang, F., Zhang, B., \& Li, L. (2015). Multiple organ dysfunction syndrome, an unusual complication of heroin intoxication: A case report and review of literature. International Journal of Clinical and Experimental Pathology, 8(9), 11826-11830.

[6] Friedman, E.A., \& Tao, T.K. (1995). Disappearance of uremia due to heroin-associated nephropathy. Am. J. Kidney Dis., 25(5), 689-693. doi: 10.1016/0272-6386(95)90543-X

[7] Garg, L., Gupta, S., Swami, A., \& Zhang, P. (2015). Levamisole/ cocaine induced systemic vasculitis and immune complex glomerulonephritis. Case Rep. Nephrol., 372-413. https:// doi.org/10.1155/2015/372413

[8] Guide for the care and use of laboratory animals. (2011). 8-th ed. Washington. The National Academies Press.

[9] Hresko, N. (2017). Changes of colon angioarchitectonics under conditions of 2-4-week opioid effect in the experiment. Deutscher Wissenschaftsherold. German Science Herald, 5, 43-48. doi: 10.19221/2017512

[10] llesanmi, O.B., \& Odewale, T.T. (2020). Effect of classic soft drink Coca-Cola as a solvent in the administration of tramadol and diazepam on biochemical and histological changes in liver and kidney. Ukrainian Journal of Nephrology and Dialysis, 3(67), 33-41. https://doi.org/10.31450/ukrjnd.3(67).2020.06

[11] Jaffe, J.A., \& Kimmel, P.L. (2006). Chronic nephropathies of cocaine and heroin abuse: a critical review. Clin. J. Am. Soc. Nephrol., 1(4), 655-667. https://doi.org/10.2215/CJN.00300106

[12] Kamyshnikov, V.C. (2011). Методы клинических лабораторных исследований [Clinical laboratory research methods]. Москва: МЕДпресс-информ - Moscow: significant changes in biochemical parameters, but the established deviations may indicate the first signs of renal dysfunction.

3. Further use of Nalbuphine, including the end of the sixth week of the experiment, leads to significant changes in the filtration and reabsorption functions of the kidneys, as evidenced by statistically significant changes in the biochemical parameters of rats' blood and urine.

MEDpress-inform, 4, 752.

[13] Logash, M., Pokotylo, P., Fedevych, Yu., \& Kryvko, Yu. (2014). Зміни біохімічних показників крові щура при інтоксикації опіоїдами в динаміці перебігу експерименту [Changes in biochemical parameters of rat blood during opioid intoxication in the dynamics of the experiment]. Експериментальна $i$ клінічна медицина - Experimental and Clinical Medicine, 3(64), 78-81.

[14] Logash, M. (2017). The effect of nalbuphine administration on the rat liver ultrastructure. Ind. J. Basic Applied Med. Res., 6(4), 305-312.

[15] Mallappallil, M., Sabu, J., Friedman, E.A., \& Salifu, M. (2017). What Do We Know about Opioids and the Kidney? Int. J. Mol. Sci., 18(1), 223. doi: 10.3390/ijms 18010223

[16] Neugarten, J., Gallo, G.R., Buxbaum, J., Katz, L.A., Rubenstein, J., \& Baldwin, D.S. (1986). Amyloidosis in subcutaneous heroin abusers "skin poppers' amyloidosis". Am. J. Med., 81(4), 635640. doi: 10.1016/0002-9343(86)90550-4

[17] Novick, T., Kuo, Y.F., Raji, M.A., Chen, N.W., Hasan, H., \& Goodwin, J.S. (2016). Trends in opioid prescriptions among part D medicare recipients from 2007 to 2012. Am. J. Med., 129(2), 21-30. doi: 10.1016/j.amjmed.2015.10.002

[18] Novick, T., Liu, Y., Alvanzo, A., Zonderman, A.B., Evans, M.K., \& Crews, D.C. (2016). Lifetime cocaine and opiate use and chronic kidney disease. Am. J. Nephrol., 44(6), 447-453. doi: $10.1159 / 000452348$

[19] Nuckols, T.K., Anderson, L., Popescu, I., Diamant, A.L., Doyle, B., Di Capua, P., \& Chou, R. (2014). Opioid prescribing: a systematic review and critical appraisal of guidelines for chronic pain. Ann. Intern. Med., 160(1), 38-47. doi: 10.7326/ 0003-4819-160-1-201401070-00732

[20] Pidvalna, U., Kost, A., \& Mateshuk-Vatseba, L. (2018). Effect of Narcotic Analgesics on the Ultrastructure of the Eyeball (Experimental Study). Journal of Morphological Sciences, 35(04), 251-254. doi: 10.1055/s-0038-1676543

[21] Porubsky, S., Kuppe, C., Maier, T., Birk, H.W., Wornle, M., Moeller, M.J. ... Grone, H.J. (2014). Renal lipidosis in patients enrolled in a methadone substitution program. Arch. Pathol. Lab. Med., 138(5), 689-693. doi: 10.5858/arpa.2013-0075-CR

[22] Rao, T.K., Nicastri, A.D., \& Friedman, E.A. (1974). Natural history of heroin-associated nephropathy. N. Engl. J. Med., 290, 1923. doi: 10.1056/NEJM197401032900105

[23] Lan, X., Rao, T. K. S., Chander, P. N., Skorecki, K. \& Singhal, P. C. (2015). Apolipoprotein L1 (APOL1) Variants (Vs) a possible link between Heroin-associated Nephropathy (HAN) and HIVassociated Nephropathy (HIVAN). Front. Microbiol., 9(6), 571. doi: 10.3389/fmicb.2015.00571

[24] Shatskyi, V.V., Hudyma, A.A., \& Blyzniuk, R.V. (2019). Вплив експериментальної гострої крововтрати, ускладненої ішемією-перфузією кінцівки, на діурез і швидкість клубочкової фільтрації [Influence of experimental acute blood loss complicated by limb ischemia-perfusion on diuresis and 
glomerular filtration rate]. Шпитальна хірургія. Журнал імені Л.Я. Ковальчука - Hospital surgery. Magazine named after L. Ya. Kovalchuk., 4, 50-58. https://doi.org/10.11603/24144533.2019.4.10710

[25] Sreepada Rao, T.K., Nicastri, A.D., \& Friedman, E.A. (1977). Renal consequences of narcotic abuse. Adv. Nephrol. Necker Hosp., 7, 261-290.

[26] Singh, V.P., Singh, N., \& Jaggi, A.S. (2013). A review on renal

toxicity profile of common abusive drugs. Korean J. Physiol. Pharmacol., 17(4), 347-57. doi: 10.4196/kjpp.2013.17.4.347

[27] Vilkhova, I.V. (2018). Морфологічні зміни канальців несрона на пізніх термінах хронічного опіоїдного впливу [Morphological changes of nephron tubules in the late stages of chronic opioid exposure]. Світ медицини та біології World of Medicine and Biology, 2(64), 131-134. doi: 10.26724 / 2079-8334-2018-2-64-131-134

\section{БІОХІМІЧНІ ПОКАЗНИКИ КРОВІ ТА СЕЧІ ЩУРІВ ПРИ ШЕСТИТИЖНЕВОМУ ВВЕДЕННІ НАЛБУФІНУ}

\section{Вільхова I.В.}

Враховуючи широке використання в медицині опіоїдних анальгетиків, сьогодні надзвичайно актуальним $\epsilon$ вивчення морфоофункціональних змін різних органів при тривалому впливі опіоїів. У сучасній науковій літературі $\epsilon$ роботи, в котрих висвітлені зміни біохімічних показників крові при вживанні наркотичних анальгетиків в експерименті. Дослідити зміни біохімічних показників крові та сечі за умови довготривалого використання налбуфріну $є$ актуальним напрямком наукового дослідження. Мета дослідження - виявити зміни деяких біохімічних показників крові та сечі щурів при шеститижневому введенні терапевтичних доз налбуфріну. Матеріалом дослідження слугували 40 білих статевозрілих щурів самців масою 180-260 г, котрим впродовж шести тижнів проводили ін'єкції налбуфріну (Nalbuphine injection $20 \mathrm{mg}$ ) щоденно, дом'язово у терапевтичних дозах. У пробах сечі визначали добовий діурез та вміст креатиніну. У пробах крові визначали вміст загального білка, креатиніну, сечовини, кальцію та фоссрору. Також визначали показник швидкості клубочкової фрільтрації за кліренсом ендогенного креатиніну. Всі статистичні обрахунки проводили із використанням програмного забезпечення R Studio v.1.1.442 ma R Commander v.2.4-4. Результати дослідження показали, що шеститижневе застосування терапевтичних доз налбуфіну впливає на фрільтраційну та реабсорбційну функції нирки. Використання налбуфріну впродовж двох тижнів не викликає достовірних змін біохімічних показників, проте встановлені відхилення можуть свідчити про перші ознаки порушення фрункцій нирок. Подальше використання налбуфріну, включно до закінчення шостого тижня експерименту, призводить до достовірних змін фрільтраційної та реабсорбційної функцій нирок, про що свідчать статистично достовірні зміни біохімічних показників крові та сечі щурів. Дані проведеного дослідження можуть бути використані для порівняння зі змінами функціонального стану нирок, викликаними тривалішим застосуванням налбуфіну, його відміною та застосуванням інших медичних препаратів у поєднанні з налбуфріном. Також результати дослідження доцільно співставити з морфологічними змінами нирок на різних термінах застосування налбуфіну.

Ключові слова: нирка, опіоїди, біохімічні показники. 